\section{The structuring of health systems and the control of infectious disease: looking at Mexico and Cuba}

\author{
Tim Anderson ${ }^{1}$
}

Key words: health policy, delivery of health care, privatization, health status indicators, communicable diseases, Cuba, Mexico.

\footnotetext{
1 University of Sydney, Political Economy, Sydney, Australia. Send correspondence to: Tim Anderson; e-mail: tima@ econ.usyd.edu.au
}

This paper considers the implications that distinct organizing principles for health systems have for the control of infectious diseases. The paper takes the health systems in Mexico and Cuba as examples of neighboring but widely divergent systems, producing different pubic health outcomes. The paper will look at the dissimilar organizing principles of these two systems, along with their programs and outcomes in relation to five of the most important and dangerous infectious diseases. The paper will then consider what broader lessons might be drawn from the experiences in Cuba and Mexico.

Mexico has pursued a federal and neoliberal system, based on tripartite social insurance (State, employer, and employee contributions), private "partnerships" (private-for-profit investment in public services), and competitive service provision (competitive rather than coordinated services). On the other hand, Cuba has maintained a public system, with guaranteed free and universal access, universal patient registration, assignment of all persons to a family doctor, and centralized public coordination of services. How have these two health systems approached tuberculosis, HIV / AIDS, diarrhea, measles, and malaria?

In recent decades both countries have made substantial progress in dealing with these five diseases, but Cuba has maintained a superior performance, despite having a lower income per capita and less total Government funding available. This at first seems to contradict the broad international correlation between income levels and health outcomes. It also poses questions for the "pro-poor" policies that the Organization for Economic Cooperation and Development (OECD) (the wealthy countries' club) suggests for developing countries. Those policies emphasize "scaling up resources and private investment," including with competitive service provision and expanded "choice" in health services $(1,2)$.

Important research (3) has demonstrated that general income growth has less correlation with reductions in major categories of mortality and with other major advances in public health than do the education of women and the implementation of appropriate technology. The question of the contribution of other social and organizational factors in reducing mortality and morbidity levels is left open. However, it is well established, for example, that major reductions in maternal mortality are much more strongly linked to the presence of a 
skilled birth assistant than to expensive facilities or high technology (4).

What then of infectious disease? In most poor and developing countries, epidemics of tuberculosis, HIV / AIDS, diarrhea, measles, and malaria are major killers. While highly controlled in most wealthy or "low-mortality" countries, these five diseases each kill many hundreds of thousands of people worldwide every year, as do poor maternalinfant health conditions and nutritional disorders. In 2002, for example, HIV / AIDS killed 2.8 million persons worldwide, tuberculosis 1.6 million, diarrheal diseases 1.8 million, malaria 1.2 million, and measles 760000 (5). Beyond the bland demands for "broad-based economic growth" (6), how might the organization of health policy be linked to substantial advances in combating these diseases?

Most of the serious infectious diseases that affect developing countries are no longer the primary health problems of the more wealthy countries. Nor are infectious diseases the main problems of Mexico and Cuba. In recent years, these two countries have been wrestling with these "preventable" diseases and, to varying degrees, have overcome them. Because of their divergent systems and their differing outcomes with infectious diseases, it seems that a comparative study of Mexico and Cuba might be enlightening.

\section{ORGANIZING PRINCIPLES OF THE MEXICAN AND CUBAN HEALTH SYSTEMS}

The structure of the Mexican health system might be summed up as a near 50-50 public-private mix in finance, a multi-institution mix of tripartite insurance, competitive service provision between and within the private and public spheres, and the notion of consumer choice in the selection of health services (7). The Cuban system, on the other hand, is an overwhelmingly public and centrally coordinated system, based on free and universal citizen access to services, with universal medical registration of the population by primary health service providers within family doctor districts (8) (Table 1).

\section{Mexico}

The Mexican health system combines several tripartite social security insurance bodies (with contributions from employees, employers, and Government), a public system, and a large private sector. The country's health system has substantial resources and expertise, but it is structurally fragmented and includes highly unequal access to services. By law, all formally employed Mexican work-
TABLE 1. Distinctive themes in the health policies of Mexico and Cuba

\begin{tabular}{ll}
\hline \multicolumn{1}{c}{ Mexico } & \multicolumn{1}{c}{ Cuba } \\
\hline $\begin{array}{l}\text { Public-private mix in funding } \\
\begin{array}{c}\text { Tripartite insurance (State, } \\
\text { employer, and employee } \\
\text { contributions) }\end{array}\end{array}$ & Public system \\
$\begin{array}{l}\text { Competitive service provision } \\
\text { between and within the } \\
\text { private and public spheres }\end{array}$ & Centralized service coordination \\
$\begin{array}{c}\text { Notion of consumer choice } \\
\text { in the selection of health } \\
\text { services }\end{array}$ & Universal patient registration \\
\hline
\end{tabular}

ers must belong to a social security institution. The Mexican Social Security Institute (MSSI) (Instituto Mexicano del Seguro Social) is by far the biggest of the social security institutions. MSSI covers workers and their families, and provides coverage for about $40 \%$ of the country's total population (7). However, a major problem with the social security system is that persons without formal employment, who constitute around $40 \%$ of the Mexican adult population (9), are not covered (although they do receive care from the public system; see below). The total insured population is probably a bit over 50 million, with the uninsured also around 50 million. Of the country's gross domestic product, about $5.4 \%$ of it (half of that amount being private) is spent on health services (7).

Each social security insurance institution has its own funding arrangements, facilities, doctors, nurses, and auxiliary personnel. These institutions could in many respects be separate empires, except that the federal Government has recently begun to play a larger coordination and funding role. Social security insurance coverage for the Mexican population remains incomplete and uneven. In the states of Chiapas and Guerrero, only $17.6 \%$ and $20.3 \%$, respectively, of the population are enrolled, while in Coahuila and Nuevo León, 69.7\% and 65.9\%, respectively, are enrolled (7). The uninsured have to rely on the public system, or they pay their own way in the diverse, largely unregulated private system. In recognition of these deficits, MSSI family schemes and the federally-funded MSSI-Solidarity scheme have been developed in recent years, in an attempt to expand coverage (10).

The private health system is far more expensive, consuming around half the country's expenditure on health, and with much higher doctors' wages. It focuses mainly on curative medicine and provides only $30 \%$ of the health facility beds and $32 \%$ of the consultations $(7,11)$. 
Resource distribution in Mexico's segmented system has some extraordinarily inefficient features. For example, this can be seen with the health system for employees of PEMEX, which is the Government-owned petroleum company, and the State Workers' Social Security and Services Institute (Instituto de Seguridad y Servicios Sociales de los Trabajadores del Estado), which is the health system for other State employees. While the State Workers' Social Security and Services Institute covers 16 times as many workers, it only has three times the resources of the PEMEX health system. Nor are the most important resources of Mexico's health system fully utilized. One survey found that roughly $27 \%$ of doctors and $43 \%$ of nurses were unemployed, inactive, or employed in other activities (7). Resources are also distributed unevenly. For example, the average doctor-to-population rate for the country is about 2.0 per 1000 people; however, in the states of Mexico and Chiapas the rates are 0.8 and 0.9 , respectively, while in Mexico City the rate is $3.2(7)$.

Both the federal Government's Health Sector Reform Program for 1995-2000 and the National Health Program for 2001-2006 stressed equitable outcomes as a central objective, but relied on the same fragmented, semiprivatized system to deliver such outcomes. The broad objectives included improving health conditions, reducing inequalities in health, and delivering justice in health financing (10). The connection between poverty and poor health was recognized: "Poor health generates, deepens, and helps to perpetrate poverty." Cardiovascular diseases, cancer, and other nontransmissible, or first-world, diseases have largely supplanted diseases related to infection, malnutrition, and reproduction as the major causes of death (10). However, the major infectious diseases still have a noticeable impact on certain segments of the Mexican population.

\section{Cuba}

The Cuban health system draws on a sustained political focus on health and on the training of large numbers of health workers. The Cuban health system is composed of the Ministry of Public Health (MPH) (Ministerio de Salud Pública), a family doctor system, a polyclinic system, the country's public hospitals, the medical training system, and pharmaceutical and research institutions. Reinforcing the importance of health policy in Cuba, the $\mathrm{MPH}$ has high standing, and the respective health ministers at the national, provincial, and municipal levels are also the designated vice-president of that level of government (personal communication,
Dr. José Portilla, Ministry of Public Health of Cuba, 27 May 2004).

The family doctor system was created in 1984 to establish $100 \%$ primary care coverage at a local level. This system now involves one or more doctors in a small office serving between 120 and 160 families, or 600 to 800 persons (12). As of 2004, about 32000 of the country's 68000 doctors were working in family doctor clinics (personal communication, Dr. José Portilla, Ministry of Public Health of Cuba, 27 May 2004). The country's entire population is registered for health services through the family doctor system (personal communication, Dr. Victoria Gómez Sánchez, Havana, 17 May 2004). Family doctors are charged with promoting health, preventing illness, providing early diagnoses, and generally attending to the needs of their families (13). There are few resources in these small offices (usually with an attached residence) other than a doctor, nurses, and some medicines. Health education covers nutrition, as well as water purification in those few parts of the island where there are no improved water sources. The family doctor clinics are coordinated under local work groups, which are in turn under a municipal administration (personal communication, Dr. José Portilla, Ministry of Public Health of Cuba, 27 May 2004).

The polyclinics are intermediate health centers. They operate at the municipal level, and have substantial resources. They carry out many of the functions of hospitals in other countries, but have no live-in patients. They may have four to six beds, but a maximum stay is eight hours. Polyclinics have maternal and other specialist doctors-in fact about $80 \%$ of specialist services-as well as dentists, an ambulance service (which now carries doctors as well as paramedics), and test labs (personal communication, Dr. José Portilla, Ministry of Public Health of Cuba, 27 May 2004).

The Cuban system is strong on planning and evaluation, regularly setting performance goals. Reviews of practice and teaching have reinforced the need to intensify primary care, and to back up these primary services with a strong organization carrying all necessary specialist services (13). A 1996 MPH review of health policy called for reinforcement of the primary care priority, through the family doctor and nurse; a revitalization of hospital care; a reactivation of technology and research programs; a consolidation of the medicines and natural medicines program; and priority for certain specialist areas, the maintenance of social assistance (including food support), and the ambulance system (14-18).

Cuba now has a comprehensive system of biomedicines, including vaccines that cover at least $95 \%$ of the population (17). The country effectively 
eliminated polio (1992), malaria (1967), diphtheria (1969), postpartum meningitis (1989), and measles (1993). There is also effective suppression of tuberculosis meningitis and of neonatal tetanus, and no incidence of mumps meningitis or of congenital rubella syndrome. There is no leprosy in the country. The country has meningococcal, hepatitis B, and leptospirosis vaccines $(14,15)$. Dengue fever was introduced into the country on three occasions (1981, 1997, and 2002), but intense campaigns have eliminated it. Tuberculosis is largely suppressed, but occasionally resurges, mainly amongst older people (personal communication, Dr. José Portilla, Ministry of Public Health of Cuba, 27 May 2004).

Cuba's economic depression of the 1990s, triggered by the collapse of its trade relationship with the Soviet Union as well as the sustained economic blockade by the United States of America, put serious pressures on the health system. Despite this, the Cuban system retains its public and universal character, with just a few private expenses creeping in, by way of private part-payment for imported items such as wheelchairs, glasses, and hearing aids (15).

\section{MANAGING INFECTIOUS DISEASES}

This paper combines data from various sources to track morbidity and mortality outcomes from five infectious diseases over the period of 1990 through 2002 in Cuba and Mexico (Table 2). The subsections below discuss each of the diseases, along with the programs used to manage them.

\section{Tuberculosis}

BCG vaccination does not seem to affect the transmission of tuberculosis. Nevertheless, since the vaccine offers a high level of protection against the most severe forms of the disease, it is recommended for very young children. The vaccine is not used with HIV-infected patients because it could initiate active disease in them $(23,24)$.

Levels of tuberculosis infection rose and fell in both Cuba and Mexico in the 1990s. By 1999 both countries had reached nearly complete vaccination coverage for one-year-olds, but vaccination occurred earlier in Cuba. Cuba's infection rate remained almost half that of Mexico's, and with far fewer disparities throughout the country. There is also a smaller chance of dying from tuberculosis in Cuba than in Mexico. In the year 2000, when Mexico's tuberculosis infection rate was double that of Cuba's, its death rate was more than six and half times as high as that of Cuba (Table 2). However, Mexico had substantially reduced its TB deaths, from over 4000 per year in the mid-1990s to just over 2500 in 2000. In Cuba just 44 people died from tuberculosis in 2000 (20).

A study in 1990 of equity in tuberculosis control around the world found that disadvantaged groups were about two and a half times more likely

TABLE 2. Incidence (per 100000 persons, all ages) of major infectious diseases, Mexico and Cuba, 1990-2002 ${ }^{\text {a }}$

\begin{tabular}{|c|c|c|c|c|c|c|}
\hline Disease & 1990-1991 & 1995 & 1997 & 1999 & 2000 & 2001-2002 \\
\hline \multicolumn{7}{|l|}{ Tuberculosis } \\
\hline Mexico: infectionb & 14.7 & 18.7 & 20.6 & 17.2 & 15.7 & $\ldots{ }^{c}$ \\
\hline Cuba: infection & 5.1 & 14.2 & . & 10.0 & 8.0 & 7.6 \\
\hline Mexico: death & 6.5 & 4.4 & 3.8 & 3.3 & 2.6 & \\
\hline Cuba: death & $\ldots$ & $\ldots$ & $\ldots$ & $\ldots$ & 0.4 & 0.3 \\
\hline \multicolumn{7}{|l|}{ HIV } \\
\hline Mexico & 3.7 & 4.8 & $\ldots$ & $\ldots$ & $\ldots$ & 3.3 \\
\hline Cuba & 0.03 & $\ldots$ & 0.2 & $\ldots$ & 0.2 & $\ldots$ \\
\hline \multicolumn{7}{|l|}{ Diarrheal deaths } \\
\hline Mexico & 22.0 & 10.5 & $\ldots$ & 6.6 & $\ldots$ & $\ldots$ \\
\hline Cuba & 3.5 & 5.0 & $\ldots$ & 3.4 & $\ldots$ & $\ldots$ \\
\hline \multicolumn{7}{|l|}{ Measles } \\
\hline Mexico & & $\cdots$ & $\cdots$ & 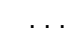 & $\ldots$ & 0 \\
\hline Cuba & 0.2 & 0 & 0 & 0 & 0 & 0 \\
\hline \multicolumn{7}{|l|}{ Malaria } \\
\hline Mexico & 18.6 & 5.4 & $\ldots$ & $\ldots$ & $\ldots$ & 4.14 \\
\hline Cuba $^{d}$ & 4.19 & 0 & $\ldots$ & 0.12 & 0.34 & $\ldots$ \\
\hline
\end{tabular}


to be ill from tuberculosis than were advantaged groups (23). In the Americas, Mexico's ratio was 6.7, which was more than Brazil's 5.3, but less than Chile's 8.0 and Jamaica's 25.1 (25). According to figures from the Mexican Secretariat of Health, infection rates in some regions of the country in 2002 were as much as 5.7 times higher than those in other regions (22). Among persons presenting with TB symptoms in Mexico, $62 \%$ of them did so at MSSI services, $28 \%$ at the public hospital system, 8.5\% through MSSI-Solidarity, and less than 1\% through the State Workers' Social Security and Services Institute. However, about $55 \%$ of the primary treatments were at public hospitals operated by the Secretariat of Health, which guarantees free treatment for all TB sufferers (21).

Cuba, like Mexico, had a surge in tuberculosis in the mid-1990s, during its economic crisis, with infection rates rising from a low of 5.1 per 100000 in 1990 to a high of 14.2 in 1995, before subsiding again to 7.6 in 2001-2002. In 1994 a tuberculosis prevention and control program was enhanced, to refocus treatment of the disease. In Cuba the highest rate of TB occurs among those who are over 65 years old, with a rate of 38.9 per 100000 in 1996, mostly pulmonary tuberculosis (15). There is greater geographical equality in Cuba than in Mexico. In Cuba in 2002 , about $85 \%$ of the 860 cases were pulmonary tuberculosis. A quarter of the cases were in Havana, and the rest were spread fairly evenly over the rest of the country. The only locations that had rates higher than the national level of 7.6 per 100000 were the provinces of Ciego de Ávila (9.7), Havana (10.3), and Villa Clara (13.3) (18).

\section{HIV/AIDS}

AIDS is caused by HIV, and is spread through blood and sexual activity and from mother to fetus (26). Prevention has focused on the risk factors, primarily educating persons to avoid engaging in unprotected sex or using unhygienic needles. Treatment includes specialist care and monitoring, expensive combinations of drugs, and medication for the opportunistic secondary diseases. So far, there is no vaccine against HIV, and the cost of AIDS treatment is simply unaffordable in many poor countries.

The disease is important in Mexico. In Mexico as of 1 January 1997 there had been 29962 AIDS cases, of which 16636 had died, 11208 were still alive, and the situation of 2118 was unknown. The mode of transmission was reported in over $70 \%$ of the cases, and of these, the virus was sexually transmitted in $86.5 \%$ of them, and by blood transfusion in $13.5 \%$ (7). According to a report published in
2000 (27), the highest rates of infection were among homosexual men, male prostitutes, and intravenous drug users. HIV infection rates among children have also been quite high. In 2002, the rate for children under one year of age was 2.71 per 100000 , compared to 3.32 for the whole population (22).

HIV infection from blood transfusion was a major problem in Mexico in the late 1980s, as there was a market for the sale of blood, and testing processes were poor. Infection from blood transfusion fell from 350 in 1988 to zero by 1999, as the sale of blood was banned and broader testing of donations and transfusions was introduced (28). In 19971998 the Mexican Government allocated HIV / AIDS funds for prevention, care, and other activities, but this money was spread through the MSSI, public, and private systems, over which the Government said it maintained "integrated attention." This coordinated program focused on preventing infection from blood transfusion, mother-to-child transmission, and sexual transmission; integrated care for patients; and mitigation of harm (28).

With respect to the outside attention on Cuba's HIV / AIDS policy, controversy over quarantine practices seems to have overshadowed the role of broad epidemiological awareness and vigilance (29-34). Widespread HIV testing was begun in 1986. By 1993, 12 million tests had been conducted, and these tests were accompanied by sexual contact tracing and testing $(29,30)$. Though the early quarantine policy seems to have been effective, foreign medical analysts attacked it as a violation of the right to freedom of movement and the norm of voluntary testing $(29,32)$. In 1989, Cuba's mandatory quarantine policy was changed to allow patients independent leave from sanatoriums, and in 1993 a further policy change was introduced, allowing patients to choose between living in a sanatorium or at home. By 2003, half of all HIV-infected Cubans still lived in sanatoriums $(31,33)$. This pattern seems to be influenced by the relatively good conditions and the richer diet available in the sanatoriums $(33,34)$. Treatment with antiretroviral medication, in any case, is freely available to all Cubans. The reasons suggested for Cuba's very low rate of HIV infection-one-twentieth of the rate in Mexicohave included the country's relative isolation from other nations; improved educational, health, and housing opportunities; and intense HIV screening and subsequent contact tracing and counseling for infected individuals. However, isolation must have been less of a factor since the mid-1990s, when the number of tourists began growing noticeably. In 2000, Cuba had two million foreign tourists visit.

Cuba produces its own generic antiviral drugs, which are available free of charge to all Cuban citizens. In 2004 there were 32 doctors assigned to 
HIV / AIDS work, with a total of 5500 cases, including 1300 deaths and 1500 ill. The rest are HIVpositive, but not ill (personal communication, Dr. José Portilla, Ministry of Public Health of Cuba, 27 May 2004). Cuba's broad-based epidemiological awareness and vigilance has undoubtedly played some role in infection control.

\section{Diarrheal diseases}

Diarrheal diseases are intestinal infections caused by a range of bacteria, viruses, and parasites. The major problems are wasting and dehydration, so fluid therapy (oral rehydration therapy) is the major treatment. Prevention focuses on improved hygienic conditions, proper nutrition, access to clean (usually chlorinated) water, safe sewage disposal, adequate sanitation, and high standards of food care and preparation, including refrigeration. Improved child nutrition, proper hygiene education (especially of mothers), and good access to medical support are also valuable in reducing the incidence of diarrhea $(35,36)$.

In Mexico there was a surge of diarrheal disease in the 1990s, which has not yet properly abated. The illness rate in 1997 was 6800 per 100 000, and as of 2001 the rate was still in that range (10). According to the United Nations, the proportion of the Mexican population with access to safe drinking water was 73\% in 1997 (9). However, the Mexican Secretariat of Health claimed that $84.3 \%$ had such access in 1999 (10). While infection rates have remained high, medical treatment has improved, and there has been increased use of oral rehydration salts (7), so that the serious consequences of diarrhea, particularly among children, have been mitigated (7). Over the course of the 1990s in Mexico, death rates from the disease were cut by more than half.

In Cuba there was also a surge in diarrheal illness and deaths in the 1990s, but from a much lower base. Treatment is close at hand, so the seriousness of the disease is generally low. However, diarrheal illness shows up large health inequalities among the provinces in Cuba, probably reflecting the differences in sewage, water supply, and general living conditions. Among the provinces in 2001, mortality rates from intestinal infections ranged from a low of 1.1 per 100000 to a high of 4.8 per 100000 (18).

\section{Measles}

Measles is extremely infectious, and nearly all persons exposed at home catch the disease. While a major killer of children, measles can be largely con- trolled through vaccination. Control measures have focused on early effective immunization, systematic vaccination at all health institutions, vaccination campaigns targeting outbreak areas, annual campaigns, and good surveillance systems $(25,37)$. Full measles vaccination is significantly correlated with lower infant mortality (37), but there has been a debate about how young to immunize babies.

Mexico was slow to extend its vaccination program, but now has near-universal coverage, with the vaccination rate rising from 54\% in 1987 to $97 \%$ in 1997. With higher vaccination rates, there was a drastic reduction in the disease (7). Cuba had 99\% vaccination by 1987 (25). Both countries now have over $95 \%$ vaccination coverage (16), and both appear to have eliminated the disease. However, in 2004 several dozen cases were reported in the Mexican capital, the Yucatan peninsula, and the state of México. There was a quick response, with the Director General of the National Center for Child and Adolescent Health saying these cases, though few, were a matter of "national security" (38).

In Cuba there were 43 deaths from measles in 1970, but only 3 in 1980. The disease has now been eliminated; there have been no registered cases since 1993 (18). However, measles vaccine is still part of basic preventative measures for all children (personal communication, Dr. José Portilla, Ministry of Public Health of Cuba, 27 May 2004).

\section{Malaria}

The malaria parasite is transmitted from person to person through the bite of the female Anopheles mosquito. In most places, eradication has proven impossible, and the mosquito and parasite have developed insecticide resistance. Current bestpractice antimalarial strategy focuses on better drainage; separating mosquito pools from housing; greater use of bed nets, personal repellents, and protective clothing; better access to affordable drugs and early treatment; the strengthening of health systems; and spraying in high-risk areas (39, 40). In recent decades, treatment of individual cases has involved using a series of prophylactic and therapeutic drugs, in efforts to keep up with developing parasite resistance (25).

Historically, malaria had been a great threat in Mexico. Malaria has been controlled to a large extent, though with noticeable exceptions. Initially, with spraying, educational programs, and medication, malaria retreated from its status as the third biggest killer in the mid-1940s (with 12 deaths per 100000 ), to 10th by the 1960s (with fewer than 2 deaths per 100 000) $(41,42)$. However, a strong resurgence in the early 1980s demonstrated that 
neither the mosquito nor the malaria parasite could so easily be eradicated (42). Resurgence of the disease led to an abandoning of eradication attempts and a recognition that malaria had become a "disease of poverty and marginalization," which had to be tackled through such measures as vector control, education, improved housing and sanitation, and better diagnosis and treatment (42).

However, in 2002, malaria was still seen in 17 of Mexico's 32 states, most strongly in the southern state of Chiapas, where several thousand new cases are registered each year $(10,22)$. A federal action plan from 2001 focused on the worst-hit states, with emphases on improving housing, covering watercourses, dealing with various reservoirs for larvae, and the detection and treatment of infections (41). Unfortunately, the demand for improved housing in Mexico is massive, with a reported 4.2 million new or improved houses needed nationwide, including 290000 in Chiapas, according to a 2003 report (9).

Cuba says it eradicated malaria (but not the mosquito) by the late 1960s, but since then there have been occasional imports by travelers from South and Central America. The Cuban approach to the disease began with vector control (dealing with stagnant water residues, and spraying), but with a recognition that the mosquito could not be eradicated (personal communication, Dr. José Portilla, Ministry of Public Health of Cuba, 27 May 2004). The advantage of the current Cuban system of full registration of the population and broad-based epidemiological awareness is that every case of the disease can be tracked down and medicated. When there are no carriers, the Anopheles mosquito cannot transmit the disease. Such control in a malariaprone region (every country around Cuba has substantial malaria) requires a very high level of organization and epidemiological watchfulness.

However, there were dengue outbreaks in Cuba in 1981, 1997, and 2002, with each one occurring due to imported cases. More than 150 people died in 1981, and 12 more in 1997 (15). In 2002 the disease appeared again in the Santiago region. After 77 days of hard work by thousands of people, the threat was removed, with no deaths (personal communication, Dr. José Portilla, Ministry of Public Health of Cuba, 27 May 2004).

\section{DISCUSSION}

Cuba's generally superior performance in disease control seems based on its universal and guaranteed access to services, along with having adequate numbers of well-trained health workers. Cuba has a doctor-to-population rate of almost 600 per 100 000, while Mexico's rate is 200 per 100000
$(7,15)$. Mexico's uneven insurance coverage leads to failings, and an expansion of supplementary private services is unlikely to reach down sufficiently to the worst-affected regions. Mexico's recent efforts to extend insurance coverage through associate and family schemes seem to have made little progress, and indeed may carry significant longterm financial risk for the country $(7,43)$. In both Cuba and Mexico, the centrality of assured access to health services is hardly surprising. Of all the wealthy, OECD countries, only the United States does not have guaranteed universal access to health care services, and it has the worst health indicators of this group. Infant and maternal mortality figures in the United States are well above the average for the 10 OECD countries that have the best infant and maternal mortality figures (44). Good health indicators in wealthy countries are linked not only to high income levels, but in almost all cases to guaranteed universal access to services.

The Cuban system of full registration of its population, combined with centralized coordination, contributes to its high levels of epidemiological awareness and vigilance. In turn, this has likely helped in its follow-up services for tuberculosis, HIV/AIDS, and diarrhea patients. Mexico, in contrast, attempts to conduct its epidemiological oversight and coordination at a federal level, but through a variety of unequal agencies, and generally at the state level. The full registration of the population in Cuba, along with broad-based epidemiological awareness, must also figure high in the country's remarkable suppression of malaria, as complete suppression requires the identification and medication of every case. It is not completely clear why Cuba's HIV infection rate is so low. The early quarantine policy may have helped, but this practice disappeared after 1989. More important is the maintenance of high levels of ongoing testing, patient registration, tracing of sexual contacts, and counseling. To this must be added universal and free access to health care, including antiretroviral medications.

The one area where Cuba's indicators showed weakness, including noticeable regional inequality, was in rates of diarrhea. This is likely related to the decline in the quality of housing and sewage infrastructure, particularly in the 1990s and especially in some of the eastern provinces. This is one area where substantial resources are needed, and where Cuba's resource limitations (seriously aggravated by the economic blockade by the United States) impose constraints on its health system. Much the same could be said for Mexico, except that here the problem is extreme inequities in such things as housing and infrastructure, rather than the absolute level of resources. Interstate inequality can be high, 
but local level inequality can be even higher. In one comparison of Mexican counties, researchers found that some well-off counties had 25 times the per capita expenditure on health, 20 times the improved water sources, twice the sewage facilities, and three times the literacy rate that the poorest counties did (45).

Comparing Mexico and Cuba allows us to reflect on the importance of organizational features in developing countries' health systems, rather than simply calling for an infusion of additional capital (2). Mexico presents an example of expanding resources but with limited improvements in health outcomes, in a semiprivatized and fragmented system, with attempts to justify inequalities through such market slogans as "competitive service provision" and "consumer choice in health services." This comparison clarifies the role that guaranteed universal access to health services plays in controlling infectious diseases, as well as the damage caused by serious regional inequalities in infrastructure and health services. The links among social inequality, unequal access to services, and poor health outcomes have been noted by others (46). This long-standing concern was behind the World Health Organization's call, a quarter of a century ago in the Declaration of Alma-Ata, for "health for all" $(47,48)$.

\section{SINOPSIS}

\section{La estructuración de los sistemas de salud y el control de las enfermedades infecciosas: un vistazo a México y a Cuba}

En este trabajo se examinan las consecuencias que tienen para el control de las enfermedades infecciosas diferentes maneras de concebir la organización de los sistemas de salud.
En particular se examinan las bases teóricas de la organización de los sistemas de salud de México y de Cuba, junto con sus programas y resultados, en conexión con cinco de las principales y más peligrosas enfermedades infecciosas: la tuberculosis, la infección por VIH y el sida, la diarrea, el sarampión y el paludismo. México ha tenido un sistema federal y neoliberal basado en un programa de seguridad social tripartito (el Estado, el empleador, y aportaciones del empleado), en consorcios del sector privado (inversiones en servicios públicos por parte de entidades privadas con fines de lucro) y en la provisión competitiva de servicios (servicios competitivos en lugar de coordinados). En cambio, Cuba ha tenido un sistema público con acceso libre garantizado para toda la población, una coordinación pública centralizada, y la inscripción de todos los pacientes sin excepción (todo miembro de la población tiene un registro médico y un médico asignado). ¿Cómo se han lidiado con las enfermedades infecciosas más peligrosas de la humanidad dos sistemas de salud con estas características? La superioridad casi invariable que ha mostrado Cuba en el control de las enfermedades parece depender del acceso garantizado que tiene todo habitante a los servicios de salud, a la coordinación centralizada del sistema sanitario y a una abundancia de trabajadores de salud bien capacitados. Por otro lado, en México la provisión desigual de servicios asistenciales no ha logrado satisfacer las necesidades de todos los mexicanos y la expansión de los servicios privados difícilmente podrá compensar las carencias observadas en las zonas más pobres del país. Las deficiencias de infraestructura y de otros recursos imponen límites sobre lo que Cuba puede alcanzar, pero son peores los resultados de salud que se obtienen con la distribución desigual de recursos en México. Comparar a México con Cuba nos permite reflexionar en torno a la importancia de las bases organizativas de un sistema de salud, impidiéndonos optar por una mayor infusión de capital sin más. Estos resultados refuerzan ciertas inquietudes que han surgido en el pasado acerca de los vinculos existentes entre la desigualdad social, el acceso desigual a los servicios, y la obtención de resultados de salud inferiores.

Palabras clave Política de salud, prestación de atención de salud, privatización, indicadores de salud, enfermedades transmisibles, Cuba, Mexico.

\section{REFERENCES}

1. Organisation for Economic Co-operation and Development. Poverty and health: Paris: OECD, World Health Organization; 2003. (DAC guidelines and reference series).

2. Sachs J. Macroeconomics and health: investment in health for economic development: report of the Commission on Macroeconomics and Health. Geneva: World Health Organization; 2001.

3. Wang J, Jamison DT, Bos E, Preker A, Peabody J. Measuring country performance on health: selected indicators for
115 countries. Washington, D.C.: World Bank; 1999.

4. De Brouwere V, Van Lerberghe W, eds. Safe motherhood strategies: a review of the evidence. Antwerp: ITG Press; 2001. (Studies in Health Services Organisation and Policy, 17).

5. World Health Organization. World health report 2003. Geneva: WHO; 2003.

6. World Bank. World development report 2004. Washington, D.C.: World Bank; 2004

7. Pan American Health Organization. Country health profile: Mexico. Availa- ble from: http://www.paho.org/english/ sha/prflmex.htm [Web site] Accessed 15 April 2004.

8. Ministerio de Salud Pública de Cuba. Anuario estadístico de salud. La Habana: MSP; 2004

9. Oficina del Alto Comisionado de las Naciones Unidas para los Derechos Humanos en México. Diagnóstico sobre la situación de los derechos humanos en México. México, D.F.: Oficina del Alto Comisionado de las Naciones Unidas para los Derechos Humanos en México; 2003. 
10. México, Secretaría de Salud. Programa nacional de salud, 2001-2006: la democratización de la salud en México; hacia un sistema universal de salud. México, D.F.; SSA; 2001.

11. Organisation for Economic Co-operation and Development. OECD economic surveys 1998: Mexico: health care reform. Paris: OECD; 1998.

12. Rojas Ochoa F. Situación, sistema y recursos humanos en salud para el desarrollo en Cuba. Rev Cubana Salud Publica. 2003:29(2):157-69.

13. Bravo EM. Development within underdevelopment? New trends in Cuban medicine. La Habana: Editorial José Martí; 1998.

14. Ramírez Márquez A, Mesa Ridel G. El proceso de desarrollo del sistema nacional de salud en Cuba. Rev Bimestre Cubana. 2002:91(16):152-61.

15. Pan American Health Organization Country health profile: Cuba. Available from: http://www.paho.org/english/ sha/prflcub.htm [Internet site]. Accessed 15 April 2004.

16. United Nations Development Programme. Human development report 2002. Deepening democracy in a fragmented world. New York: Oxford University Press; 2002.

17. Cuba, Biblioteca Virtual de Salud. Anuario estadístico de salud de Cuba 2000. Available from: http://bvs.sld.cu/ anuario [Internet site]. Accessed 15 April 2004.

18. Cuba, Biblioteca Virtual de Salud. Anuario estadístico de salud de Cuba 2002 Available from: http://bvs.sld.cu/ anuario [Internet site]. Accessed 15 April 2004.

19. Pan American Health Organization. Average annual incidence from selected diseases under surveillance, by subregion of the Americas, 1980 and 1997. Available from: http://www.paho.org/ English/SHA/subindb98mb.htm [Internet site]. Accessed 15 April 2004.

20. Infomed. Aspectos generales del sistema nacional de salud. Available from: http://www.infomed.sld.cu. Accessed 10 May 2004.

21. México, Secretaría de Salud. Programa de acción: tuberculosis. México, D.F.: SSA; 2001.
22. México, Secretaría de Salud. Información epidemiológica de morbilidad 2002. México, D.F.: SSA; 2003.

23. Kuusi M. Tuberculosis. In: Lankinen KS Bergström S, Mäkelä PH, Peltomaa M, eds. Health and disease in developing countries. Oxford: MacMillan; 1994. Pp. 177-84.

24. World Health Organization. WHO pushing to rapidly scale-up measures to fight TB and HIV [news release]. Available from: http://www.who.int [Web site]. Accessed 15 April 2004.

25. World Health Organization. World health report 1999. Geneva: WHO; 1999.

26. Tarantola D. The AIDS pandemic. In Lankinen KS, Bergström S, Mäkelä PH, Peltomaa M, eds. Health and disease in developing countries. Oxford: MacMillan; 1994. Pp. 185-94.

27. Izazola Licea J. Sistemas de información de respuestas nacionales contra el SIDA. México, D.F.: Programa Conjunto sobre SIDA de las Naciones Unidas; 2000.

28. México, Secretaría de Salud. Programa de acción: VIH/SIDA e infecciones de transmisión sexual (ITS). México, D.F.; SSA; 2002.

29. Scheper-Hughes N. AIDS, public health and human rights in Cuba. Lancet. 1993;342(8877):965-7.

30. Perez-Stable E. Cuba's response to the HIV epidemic. Am J Public Health. 1991; 81(5):563-7.

31. Hansen H, Groce N. Human immunodeficiency virus and quarantine in Cuba. JAMA. 2003;290(21):2875.

32. Bayer R, Healton C. Controlling AIDS in Cuba. The logic of quarantine. N Eng J Med. 1989;321(12):829-30.

33. Holtz T. Summary of issues of HIVAIDS in Cuba. APHA Cuba tour, August 1997. Available from: http://www. cubasolidarity.net/cubahol2.html [Internet site]. Accessed 15 April 2004.

34. Bauza V, Collie T. HIV-positive Cubans get care but live in quarantine. South Florida Sun-Sentinel 2001. July 7:A4.

35. Rutstein SO. Factors associated with trends in infant and child mortality in developing countries during the 1990s. Bull World Health Organ. 2000;78(10): 1256-70.

36. Timo V, Torun B. Diarrheal diseases. In Lankinen KS, Bergström S, Mäkelä PH,
Peltomaa M, eds. Health and disease in developing countries. Oxford: MacMillan; 1994. Pp. 135-46.

37. Aaby P, Samb B. Measles and its control: dogmas and new perspectives. In: Lankinen KS, Bergström S, Mäkelä PH, Peltomaa $\mathrm{M}$, eds. Health and disease in developing countries. Oxford: MacMillan; 1994. Pp. 163-76.

38. Agencia APRO. Aumentan casos de sarampión. Voz Caribe 2004. 27 April:C5.

39. Whittle H, van Hemsbrook MB. Malaria. In: Lankinen KS, Bergström S, Mäkelä $\mathrm{PH}$, Peltomaa M, eds. Health and disease in developing countries. Oxford: MacMillan; 1994. Pp. 147-62.

40. World Health Organization. World health report 2002. Geneva: WHO; 2002.

41. México, Secretaría de Salud. Programa de acción: enfermedades transmitidas por vector. México, D.F.: SSA; 2001.

42. Grajales Albores J, Quintero Cabanilles R. Cronicón del paludismo: cronicón de los aspectos más relevantes de la lucha contra el paludismo en México y Chiapas. México, D.F.; 1997.

43. Soria VM. Pensions in Mexico: a longterm risk. Voices Mex. 2004;(66):53-8.

44. United Nations Development Programme. Human development report 2003. Millennium Development Goals: a compact among nations to end human poverty. New York: Oxford University Press; 2003.

45. Franco F, Ramírez T, Hernández P, Torres JL. Mexico: marginality, need and resource allocation at the county level. In: Evans T, Whitehead M, Diderichsen F, Bhuiya A, Wirth M, eds. Challenging inequities in health: from ethics to action. Oxford: Oxford University Press; 2001. Pp. 284-90.

46. Daniels N, Kennedy BP, Kawachi I. Why justice is good for our health: the social determinants of health inequalities. Daedalus. 1999;128(4):215-51.

47. World Health Organization. Alma-Ata 1978: primary health care, health for all series, no. 1. Geneva: WHO; 1978.

48. World Health Organization. Health for all: origins and mandate. Available from: http://www.who.int/archives/ who50/en/health4all.htm [Internet site]. Accessed 15 April 2004. 